\title{
OPINION: REDBERRY LAKE SANCTUARY - WILL THE PELICANS SURVIVE?
}

C. STUART HOUSTON, 863 University Drive, Saskatoon, Saskatchewan. S7N OJ8

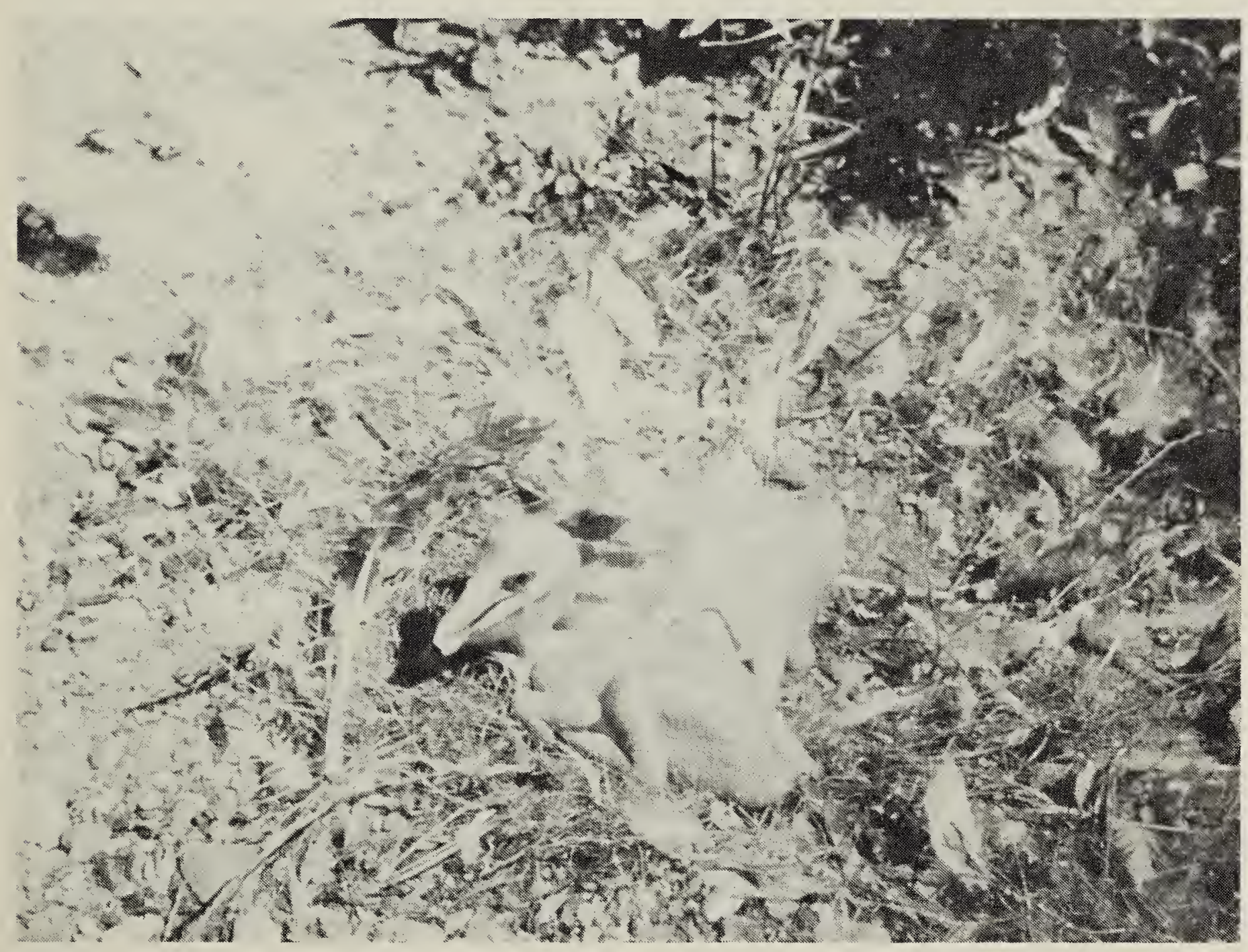

Young pelicans about a week old, vulnerable to hot sun when adult flushed from nest

C.S. Houston

Recent plans for a massive commercial development at Redberry Lake, $100 \mathrm{~km}$ northwest of Saskatoon, Saskatchewan, are highly controversial and of particular concern to naturalists. From the perspective of 32 years of banding birds there, I am convinced that Redberry Lake is one of western Canada's most important bird sanctuaries.

What are the issues in this confrontation? On the one hand, conservationists see only problems: one endangered bird species, one threatened species, and the continent's best-researched population of a third; a stagnant lake with no outlet; dropping water levels; increasing salinity; unstable, slumping slopes; a shoreline that is sometimes sandy, sometimes muddy.

On the other hand, commercial interests favouring "development" see the issues in terms of an increasing demand for resort areas; the proximity to Saskatoon; development and employment prospects; an innovative (but expensive, short-term and still experimental) fishstocking plan. 
Who will win? Piping Plovers, White Pelicans, White-winged Scoters and the environmentalists? Or the bank accounts of a selected few? I would like to share with other naturalists my wildlife perspective on this debate.

Plans for a double-barrelled project at Redberry Lake were unveiled early in 1985. On the one hand, Saskatchewan Fisheries announced a 5-year program to stock the lake with 650,000 Rainbow Trout each year, at an annual cost of $\$ 70,000$. At the same time, Boris Mamchur announced plans to build a $\$ 3.5$ million resort at Redberry Lake, complete with a lodge, a restaurant, a gas bar, a 375-lot cottage subdivision, and a 360-stall marina.

A dramatic controversy immediately arose. The pros and cons got front-page attention in the Battleford Telegraph on 26 April and the Saskatoon Star-Phoenix on 30 April (1985). Facts and opinions were intermingled as Redberry Lake became a hot news topic on radio and television as well as in the newspapers.

Politically, the fact that Paul Meagher, Progressive-Conservative MLA for Prince Albert, was a partner of Boris Mamchur in the proposed development while simultaneously serving as legislative secretary to the Minister of Parks and Renewable Resources led to charges of a possible conflict of interest. On 2 May, Meagher was suspended as legislative secretary to the department.

Socio-economically, the prospect of investment and jobs took precedence with the local councils of the town of Hafford, the rural municipality of Redberry, and the board of the regional park. All expressed support for the development.

A vocal minority, however, quickly organized to offer effective opposition. Connie Gramiak, a bee-keeper at the southwest corner of Redberry Lake, organized the Redberry Environmental Group and soon obtained about 100 local signatures opposing the development. These vigorous opponents of development did their homework more thoroughly than their opponents. Connie Gramiak and her group soon had the support of the Saskatchewan Wildlife Federation, the Saskatchewan and Saskatoon Natural History Societies, the Canadian Nature Federation and the World Wildlife Fund.

From the hydrological perspective, Redberry Lake is a "dead sea," an internal drainage basin (lake without an outlet), similar to Utah's Great Salt Lake. Unlike its southern counterpart whose water levels have recently risen higher than in recorded times, Redberry's water levels have decreased drastically and fairly steadily throughout this century. A 1906 survey showed a shoreline as much as 1200 feet horizontally beyond (even farther in the southwest corner) and about 12 feet vertically above the present shoreline. When W.W. Coleman published his photographs of a large pelican colony and a small cormorant colony in the late 1930s, Pelican Island was small with only the rocky upland portion of the present island above water. $^{2}$

When Mary and I first visited the lake with George Ledingham and Frank Roy in 1955, there was a pelican island near the south end and two gull islands in the north end of the lake. As water levels dropped, the two gull islands fused to form an island about $1 \mathrm{~km}$ long. Later, about 1963, "New Tern Island" emerged from the waters in the southwest corner of the lake. In wet years water levels roughly hold their own, but in dry years the lake recedes.

Saline lakes have the advantage of increased buoyancy for swimmers. The corresponding disadvantage is that you 
must shower with fresh water after swimming, to remove the irritating salt particles. Those using fast motorboats soon find their windscreen nearly opaque with salt.

From the limnological point of view, the decreasing water levels have caused increasing salinity. ${ }^{8}$ In 1940, whitefish were introduced into the lake and for years provided commercial fishing in winter, until the lake gradually became too salty to support any type of freshwater fish. Rainbow Trout, like most members of the salmon family are "anadromous." In their natural environment they hatch in freshwater rivers and then move to the ocean to mature before returning to spawn in fresh water. In the early 1980s, experiments showed that Rainbow Trout appeared to be the only realistic candidate available for fish restocking. Redberry's current salinity, two-thirds that of the ocean, is not a problem for Rainbow Trout, but the lake's unusual composition of salts, including a high concentration of magnesium, could cause difficulty. The Rainbow Trout may or may not succeed.

Anglers may or may not take full advantage of this new opportunity. Different fishing techniques, including fishing with worms and fly-fishing, are possible and may be necessary to have successful angling; we have relatively few dedicated fly-fishermen in Saskatchewan. Finally, the $\$ 70,000$ annual expense of Rainbow Trout introduction greatly diminishes the attractiveness of the venture. ${ }^{5}$ The 1985 Rainbow Trout introduction was a failure, but the 1986 introduction shows signs of success.

Geologically, the site chosen by the developers leaves much to be desired. I looked at stereoscopic aerial photographs of Redberry Lake with engineering student and Rhodes scholar, John Melin. John pointed out that most other shores of the lake are stable, but the slopes on the west side where the development is proposed, appear unstable. Watering of lawns in the development would be harmful and cause slumping, and cottage foundations might sag. I demonstrated before TV cameras in 1985 the muckiness of the shoreline, with my bare feet disappearing in the muck at each step, a striking contrast to nice sand beaches at the northwest and southeast corners of the lake.

Over and above all these considerations, it is the ecologica! viewpoint that merits our attention. I wish to tell you why.

First are the gulls. Ring-billed and California Gulls are a valuable economic asset to the surrounding area, as they eat prodigious quantities of insects, ranging out for $80 \mathrm{~km}$ from their nests to gather food for their hungry young. The absence of serious grasshopper infestation around Redberry Lake in recent years, in striking contrast to much of the province, is, I believe, largely attributable to these gulls.

Although gulls can withstand much more human pressure than the other colonial birds, it is nevertheless a fact that no young gulls have been raised on Gull Island, opposite the regional park, in $1982,1983,1984,1985$ or 1986 . Up to and including 1981, this long island was Redberry's major gull production area, with several thousand pairs producing thousands of young each year. It seems that each year more large boats zip around this island, pulling more waterskiers and even parachute gliders from the modest but increasingly busy Regional Park on the opposite shore. On weekends there are, as William Langley said at the Hafford hearing on 8 May 1986, "too many hot dogs, hamburgers, honky-tonks and Honda bikes." We strongly suspect, from canine footprints in the muddy shore, that cottageowners' dogs have somehow reached the 


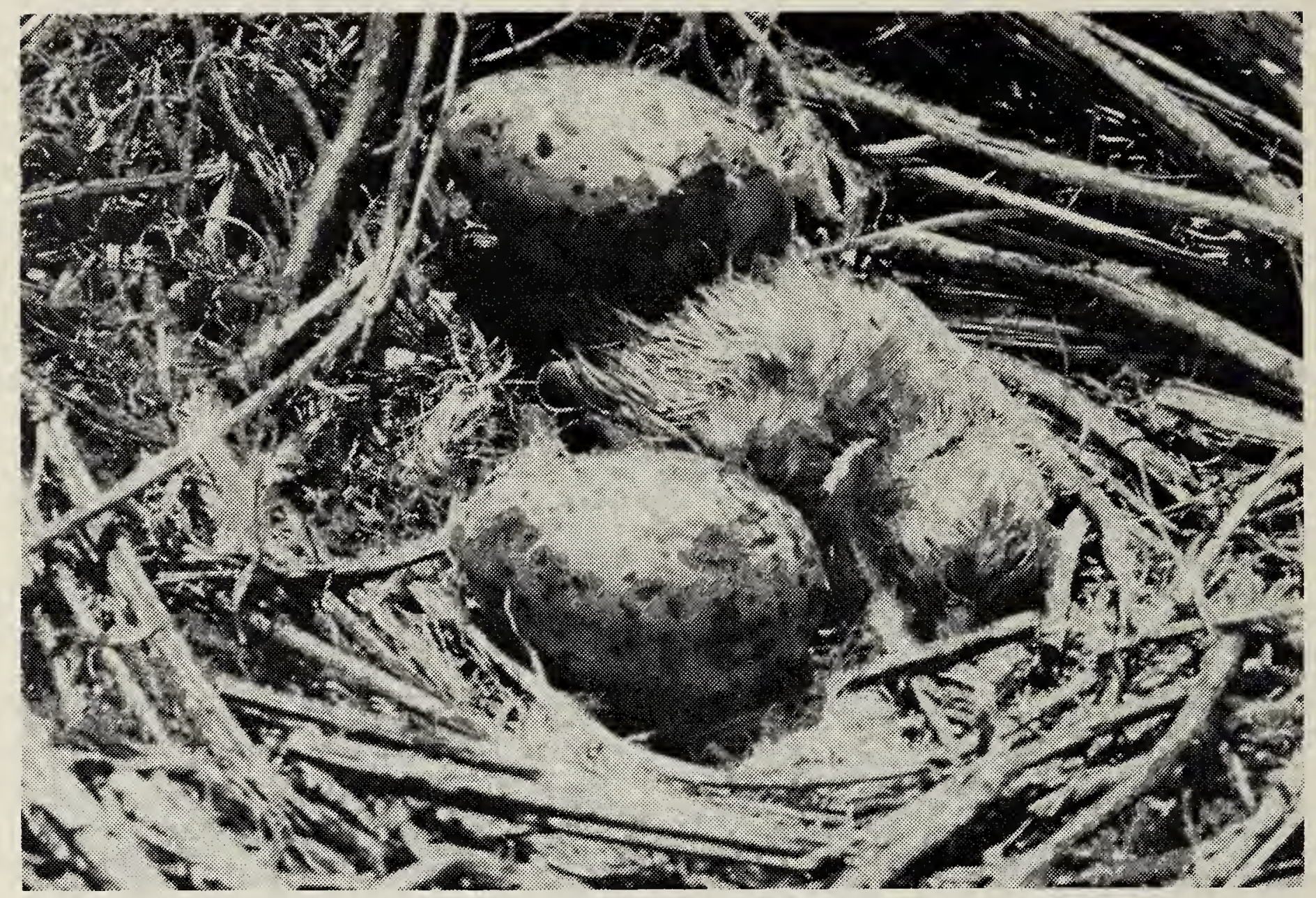

Ring-billed Gull chick and egg

Larry A. Morgotch

island on occasion and may have been the cause of massive nest desertion.

Dislocation of thousands of gulls has had an adverse effect on the other birds, particularly the Common Terns. The terns once had to themselves the small island in the southwest corner of the lake, which emerged about 1963. Since then most terns have nested near its rocky northern tip. Beginning in 1981, this part of the little island became crowded with the displaced gulls, causing a much higher mortality of nestling terns from the predatory gulls. Finally, in 1986, the terns moved to a grassy slope near the southeastern part of this island and enjoyed reasonable success for the first time in five years.

Next are the American White Pelicans, classed as a "threatened" species because so few lakes in North America remain with undisturbed islands on which they can nest. Nearly one-third of the world's remaining pairs nest on about 10 Saskatchewan lakes. ${ }^{9}$ Highly specialized birds, with large 13-litre gular pouches for scooping up minnows, their beaks literally, as the well-known verse tells us, "hold more than their belly can." These birds nest on islands because they are so large and clumsy, and vulnerable to mammalian predators on land, even though they are such graceful birds in the air.

Pelicans leave their nests whenever humans approach. When pelicans are flushed from their nests during the egg season, the braver gulls puncture and eat the pelican eggs. The young pelicans when first hatched are completely naked, and in the hot mid-day sun, or during cooler wet weather, may perish within 10 minutes after the sheltering 
Table 1. PELICANS AND CORMORANTS BANDED AT REDBERRY LAKE

\begin{tabular}{|c|c|c|c|c|c|}
\hline Year & Days & \multicolumn{2}{|c|}{ White Pelican } & \multicolumn{2}{|c|}{ D-c Cormorant } \\
\hline 1955 & 23 July & 82 & $(100+$ unbanded $)$ & 10 & $(20+$ unbanded) \\
\hline 1956 & 1, 11 July & 259 & & 46 & \\
\hline 1957 & 10 July & 123 & & 0 & \\
\hline 1958 & 30 June & 233 & $(30+$ too small) & 61 & \\
\hline 1959 & no visit & & & & \\
\hline 1960 & 25 June & 87 & $(30+$ too small) & 0 & \\
\hline 1961 & 25 June, 23 July & 222 & & 5 & \\
\hline 1962 & no banding & & & & \\
\hline 1963 & 14 July & 47 & & 0 & \\
\hline 1964 & 12 July & 190 & & 39 & \\
\hline 1965 & i July & 77 & & 50 & \\
\hline 1966 & 1,9 July & 182 & & 64 & \\
\hline 1967 & 16 July & 111 & (139 nests) 11 & 25 & (5 too small) \\
\hline 1968 & 2,15 July & 88 & & 52 & \\
\hline 1969 & 1,12 July & 55 & & 60 & \\
\hline 1970 & 3,25 July & 114 & & 29 & \\
\hline 1971 & 29 June & 131 & (80 nests) 1 & 35 & \\
\hline 1972 & 28 June & 99 & & 17 & \\
\hline 1973 & 8,19 July & 72 & & 19 & \\
\hline 1974 & no visit & & & & \\
\hline 1975 & 4,16 July & 109 & & 13 & \\
\hline 1976 & 10 July' & 142 & (89 nests,CWS) & 21 & \\
\hline 1977 & 1 July & 149 & & 34 & \\
\hline 1978 & 1,20 July & 39 & (72 nests) 12 & 10 & (24 nests, Roney) \\
\hline 1979 & 7 July & 123 & & 12 & \\
\hline 1980 & 5 july & 156 & $\begin{array}{l}\text { (168 nests) } 13 \\
\text { (6 too imall) }\end{array}$ & 59 & $\begin{array}{l}\text { (43 nests, Roney) } \\
\text { (4 too small) }\end{array}$ \\
\hline 1981 & 4 July & 154 & & 41 & \\
\hline 1982 & 4,12 luly & 175 & (240 nests,CWS) & 77 & \\
\hline 1983 & 2 July & 145 & & 20 & (40 dead hailstorm) \\
\hline 1984 & 5 July & 163 & & 42 & \\
\hline 1985 & 5 July & 192 & (347 nests, CWS) & 89 & \\
\hline 1986 & 7 July & 257 & & 109 & \\
\hline TOTALS & & & 4276 & 1039 & \\
\hline
\end{tabular}

NOTE: CWS = Canadian Wildlite Service survey. CWS and Roney nest counts were by aerial survey, 1967 by boat visit.

Parent flies off. Overall numbers of pairs nesting at Redberry have actually increased in recent years (Table 1$) .1781213$ yet the number of young fledged per nest decreased after 1976, when 1.6 young were produced per active nest, falling to $0.5,0.7$ and 0.6 young per nest, respectively, in 1978, 1982 and 1985. 


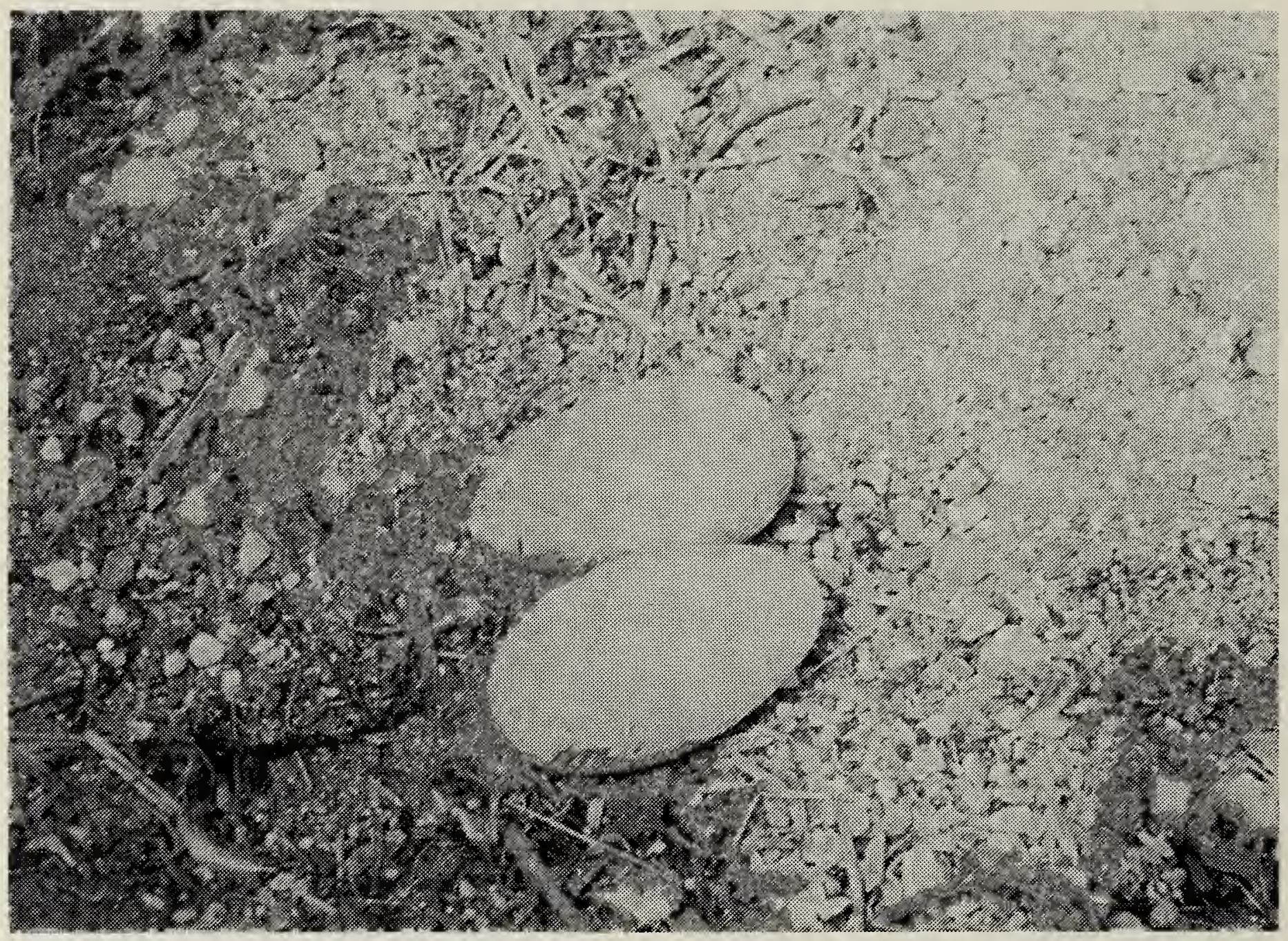

Pelican nest, vulnerable to gull predation when adult flushed

C.S. Houston

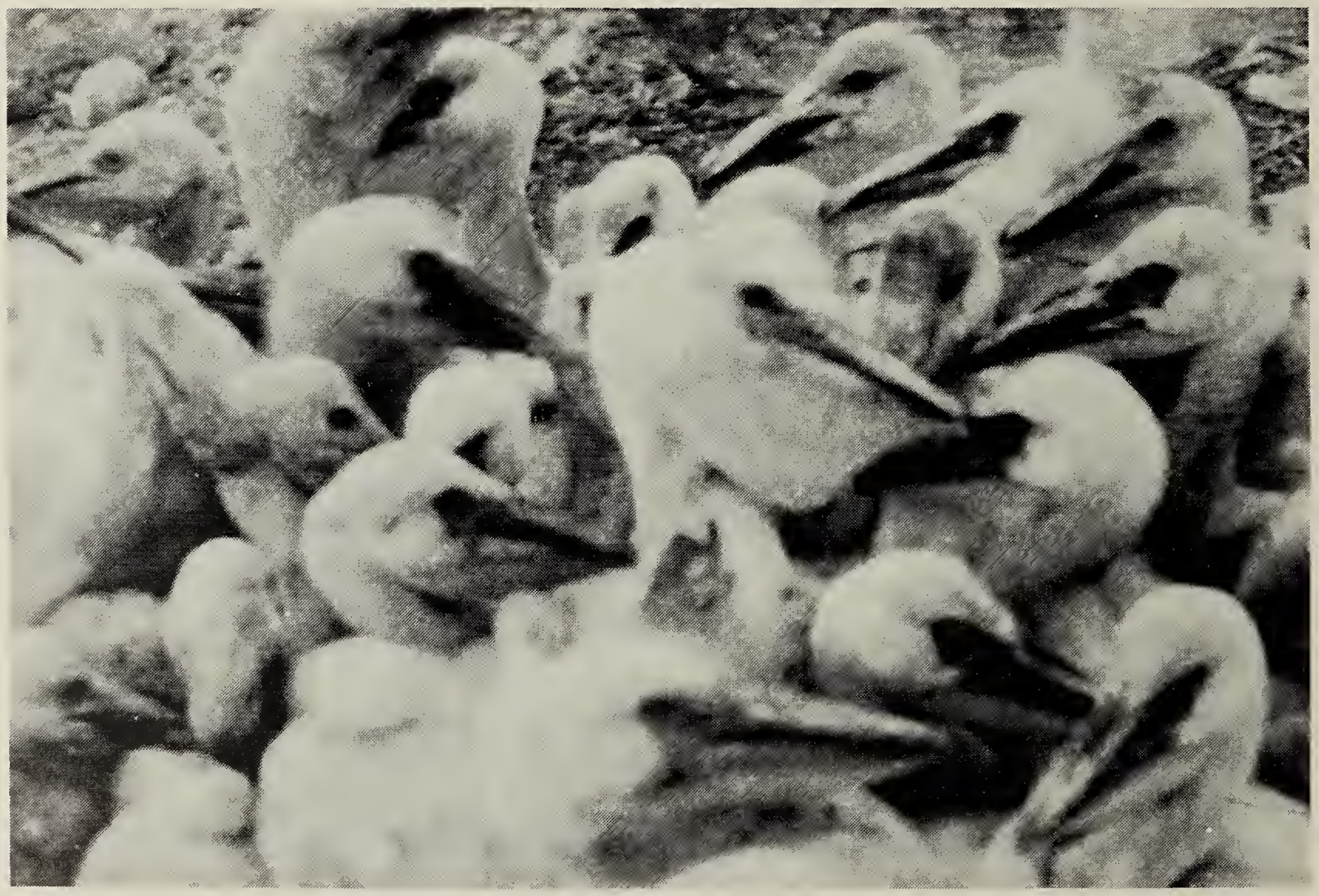

Young American White Pelicans at Redberry Lake

R.W. Cram 
The White-winged Scoter is one of our most specialized ducks. It is heavy, weighing more than a mallard, and is clumsy in taking flight. It prefers to nest on islands. My initial banding of this species was random and unplanned, involving adults caught as I reached into a gooseberry clump to pick up a young gull or pelican. Redberry Lake islands have the most concentrated nesting populations ever reported, and I therefore encouraged and assisted graduate students from the Universities of Missouri, Maine and Guelph to do scientific studies here. Pat and Mary Ann Brown and their assistants did intensive research on scoters for six summers (1975-1980) and Pat Kehoe and his assistants resumed the studies in 1984 and 1985. Most of what is known about this species in North America has been learned at Redberry Lake.
As a result of concentrated efforts to recapture randomly banded females, the Brown-Kehoe-Houston team holds the records for the six oldest White-winged Scoters in North America. The oldest is a female, which I banded on her nest in July 1969, and which Pat Kehoe recaught on her nest in 1985. Since scoters do not nest before they are two years old, this duck was at least 18 years old when recaptured!

West of "Gramiak Island", now Gramiak peninsula because of low water levels, is the channel that acts as the "creche" site where most of the surviving scoter ducklings not devoured by the gulls are reared. This channel was due to be obstructed by a large marina, but the developer, when informed of the ecological importance of the channel, eliminated the marina from his overall plan.

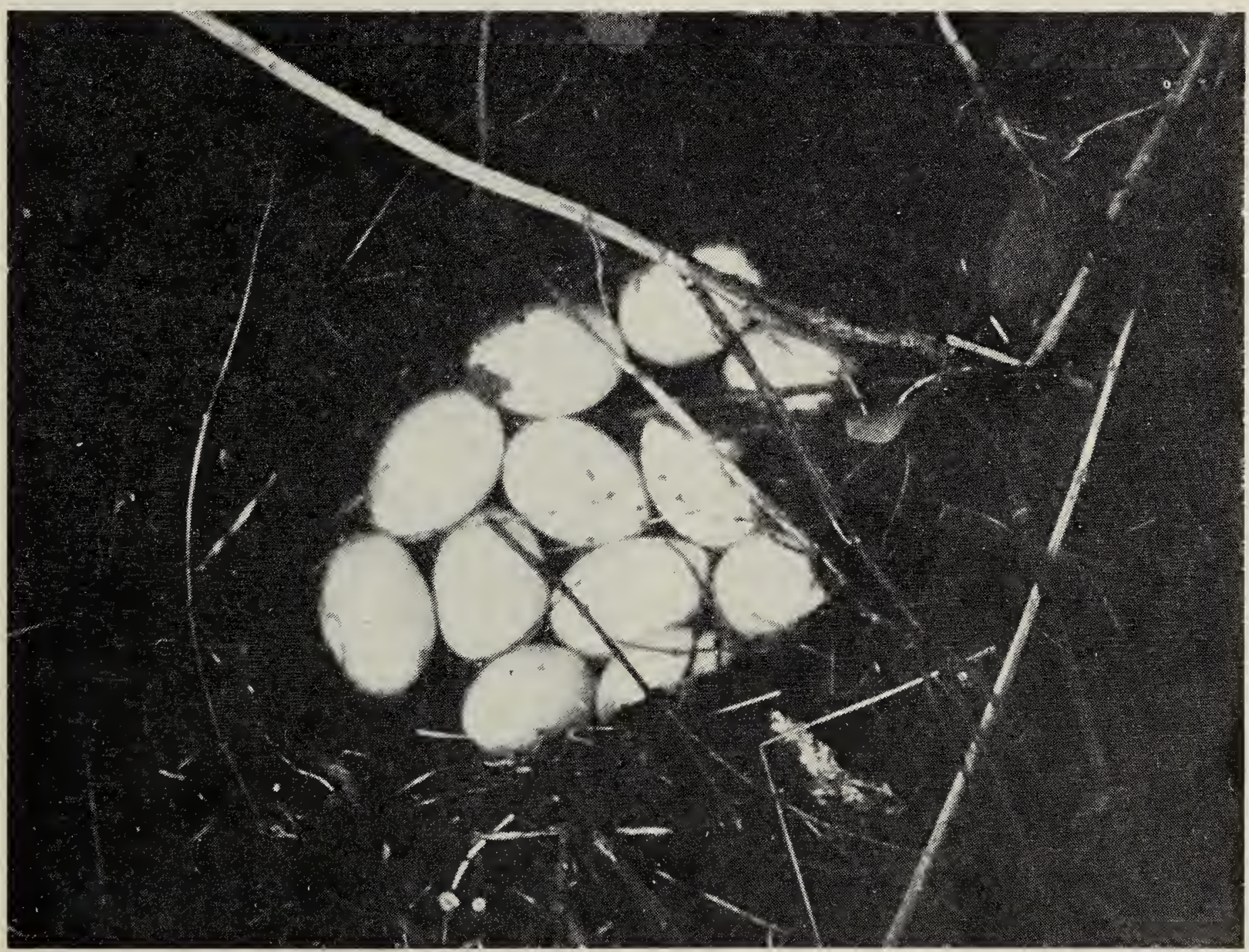

White-winged Scoter nest

C.S. Houston 
Finally, the endangered Piping Plover was one of the most typical birds of the Redberry beaches in the 1950s and 1960s, distributed around the entire shoreline, both island and mainland. Human pressures throughout North America have since had a more adverse effect than anticipated, and the North American Piping Plover population has declined to roughly 3000 pairs. Close to half of the remaining pairs of this beautiful little bird breed on a relatively small number of Saskatchewan lakes. The developer has made much of the fact that a one-visit survey in 1984 found no birds on the beach area slated for development; ${ }^{3}$ this part of the beach also did not have deer or grouse habitat and was therefore removed from the "critical wildlife habitat" designation. However, a pair of Piping Plovers nested on this very segment of shoreline in 1985 (Jim Slimmon watched the female settle on her eggs) and again in 1986.

Some government activities have helped. Relatively modest and infrequent protection efforts by governments have paid large dividends on a small investment. First reserved for a federal migratory bird sanctuary in 1915, the Saskatchewan government proclaimed the islands of Redberry lake as a game preserve in 1947.

The Saskatoon Natural History Society proposed in 1962 that "...the islands of Redberry Lake and the waters within half a mile of the islands be preserved unmolested." In reply, the Honourable A.G. Kuziak, then Minister of Natural Resources, assured the society that his department planned "no recreation developments for Redberry lake in the immediate future." (Blue Jay 20:77,1962). However, regional parks soon became the rage and the Redberry Lake Regional Park was proclaimed by the Saskatchewan Department of Culture and Youth in 1968.
Signs were placed on the main nesting island, "Pelican Island," in the 1960s by the Canadian Wildlife Service and the Saskatchewan Department of Parks and Renewable Resources. These made a noticeable impression on most members of the boating public, for beer bottles and cans thereafter ceased to be found in and near the pelican colony. A much larger sign, with large print proclaiming that visitors must keep $100 \mathrm{~m}$ distance from the island, was erected in the fall of 1985 and may have contributed to the large number of young pelicans banded in 1986 (257, surpassed only once by the 259 raised in 1956). Assuredly most members of the public are motivated by curiosity, not maliciousness, when they land at a pelican colony. Although most are ignorant of the risk they pose to the birds, the vast majority are law-abiding and are influenced by well-placed, informative signs. The small minority, forming the class of "ecologic vandals", were encountered only once at Redberry: one year young people with their boat and large motor repeatedly ran over the young gulls swimming in the water, killing and maiming them, in spite of our shouts and fists waved from the nearby shore.

Saskatchewan is blessed with literally thousands of northern lakes that are suitable for recreation with only minimal disadvantageous impact on wildlife. Redberry Lake, in striking contrast, has been a precious, unique sanctuary since 1915. It has served as an outdoor laboratory, first for limnologists and later for ornithologists, and has been the site of important long-term studies. It contains sensitive species that cannot, much as we would like to pretend otherwise, coexist for long with heavy human use. Roundthe-clock protection of the Redberry Lake islands would require three full-time wardens for three months each summer, an expense that government is not likely to undertake; even such coverage could 
not prevent every brief, damage-causing visit to the islands. Redberry Lake lacks the protection afforded Lavallee Lake the third largest pelican colony in North America) by remoteness and restricted access within a National Park.11 it is more likely to follow the same path as Last Mountain Lake, where human pressure has prevented appreciable nesting success since $1954 .{ }^{4}$ The gradual development of the regional park has already taken a heavy toll on nesting gulls, allowing one to extrapolate with some certainty concerning the damaging effects a large commercial development would inflict on both pelicans and plovers.

Should Redberry's convenient proximity to Saskatoon, its chief attraction, be allowed to destroy forever its present capacity to raise annual crops of scoters, pelicans and Piping Plovers? As Connie Gramiak said at the Hafford hearing, the question to be answered is this: Should Redberry Lake enrich all of us spiritually or a few of us financially?

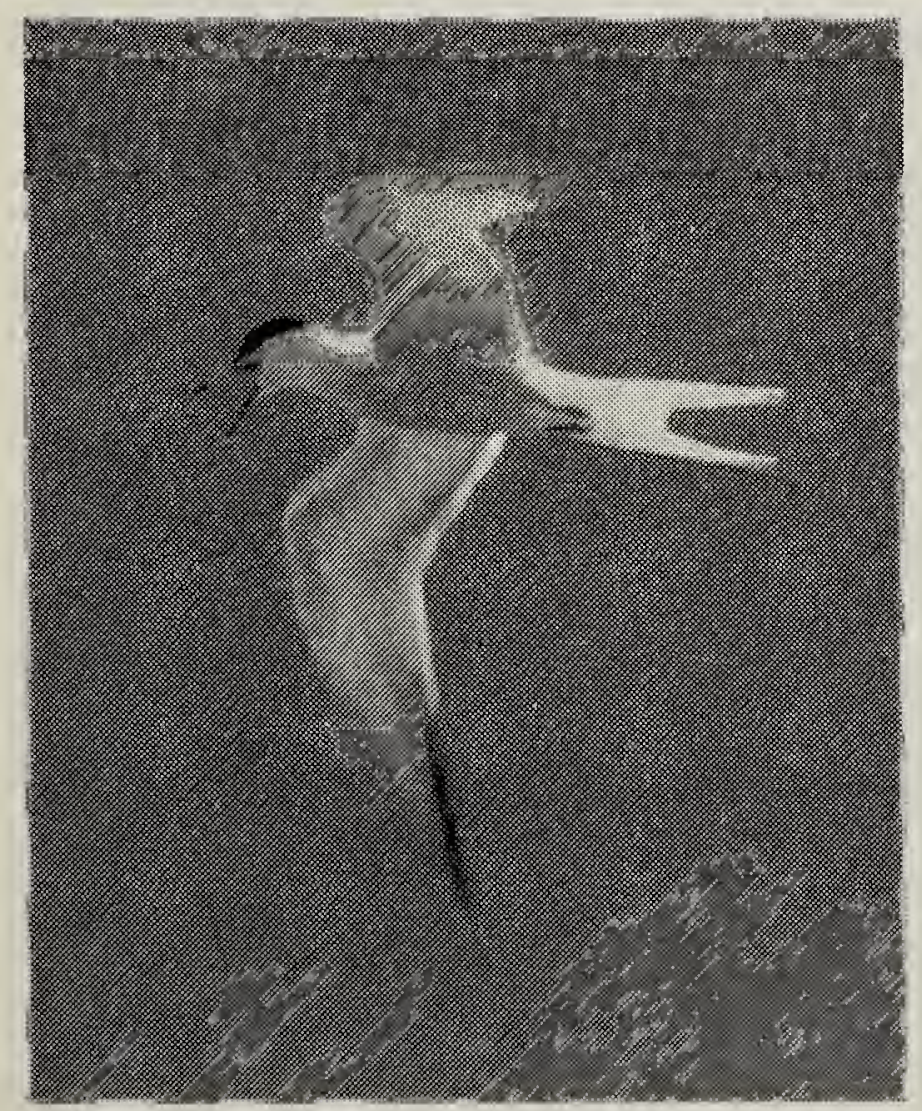

Common Tern, Redberry Lake I. Asai
'BOEKER, E.L. 1972. A survey of white pelican nesting colonies in 1971. Am. Birds 26:24, 125 .

${ }^{2}$ COLEMAN, W.W. 1938. Wings over Redberry Lake. Can. Geog. J. 15:92-101.

${ }^{3}$ HARRIS, W.C., G. WAPPLE, R. WAPPLE, K. DESMET, and S. LAMONT. 1985. Saskatchewan Piping Plovers, 1984. Raymore: Prairie Environmental Services for the Saskatchewan Natural History Society. 107 pp.

${ }^{4}$ HOUSTON, C.S. 1962. Hazards faced by colonial birds. Blue Jay 20:74-77.

${ }^{5}$ LIAW, W.K. and F.M. ATTON. 1981. Acid rain on northern lakes: background studies in Saskatchewan. Musk-ox 28:26-42.

${ }^{6}$ OROSZ, L. 1986. Creating a fishery: the largest rainbow trout stocking program in Saskatchewan's history has had its share of problems. Western Sportsman 18(4):36-40.

${ }^{7}$ RONEY, K. 1979. Saskatchewan's pelicans and cormorants in 1978. Blue Jay 37:216-218.

8RONEY, K. 1982. 1980 nest census of Saskatchewan's pelican and cormorant colonies. Blue Jay 40:158-160.

"RAWSON, D.S. and J.E. MOORE. 1944. The saline lakes of Saskatchewan. Can. /. Research D22:141-201.

10SIDLE, J.G., W.H. KOONZ, and K. RONEY. 1985. Status of the American White Pelican, an update. Am. Birds 39:859-864.

"TROTTIER, G.C., R.J. BRENEMAN, and N.A. YOUNG. 1980. Status and foraging distribution of White Pelicans, Prince Albert National Park, Saskatchewan. Can. Field-Nat. 94:383-390.

12VERMEER, K. 1970. Distribution and size of colonies of white pelicans, Pelecanus erythrorhynchos, in Canada. Can. 1. Zoology 48:1029-1032.

13VERMEER, K. 1970. Colonies of Doublecrested Cormorants and White Pelicans in Saskatchewan. Can. Field-Nat. 84:39-42. 